\title{
Cardiovascular surgery and organ damage: Time to reconsider the role of hemolysis
}

\author{
Iris C. Vermeulen Windsant, MD, ${ }^{\mathrm{a}, \mathrm{b}, \mathrm{d}}$ Sebastiaan J. Hanssen, MD, ${ }^{\mathrm{a}, \mathrm{c}, \mathrm{d}}$ Wim A. Buurman, PhD, ${ }^{\mathrm{a}, \mathrm{b}}$ and \\ Michael J. Jacobs, MD, $\mathrm{PhD}^{\mathrm{a}, \mathrm{c}, \mathrm{d}}$
}

Cardiovascular surgery with cardiopulmonary bypass is associated with postoperative organ injury, which severely affects patient morbidity and mortality. Multiple cardiopulmonary bypass-related mechanisms have been linked to the development of tissue damage, including hypoperfusion, ischemia-reperfusion, and induction of a proinflammatory response. Hemolysis, resulting in increased plasma free hemoglobin concentrations, is generally considered an inevitable but relatively harmless side effect of cardiopulmonary bypass. Recently, however, evidence has been mounting that plasma free hemoglobin scavenges intravascular nitric oxide, thereby attenuating its bioavailability. Any significant reduction in nitric oxide, the most important endogenous vasodilator, impairs tissue perfusion and induces organ injury development. Moreover, urinary free hemoglobin contributes to renal damage, specifically by catalysis of reactive oxygen species formation. In this review, the effects of increased free hemoglobin levels on nitric oxide metabolism are discussed. In addition, we review the role of free hemoglobin in organ injury development, potential sources of free hemoglobin during cardiovascular surgery, and therapeutic options to attenuate the consequences of hemolysis. We propose that hemolysis is more than an innocent bystander effect of cardiopulmonary bypass-assisted surgery. Therapeutic interventions to attenuate the effects of hemolysis seem crucial in the reduction of postoperative morbidity and mortality after cardiovascular surgery.

Cardiovascular surgery with extracorporeal circulation is associated with considerable postoperative morbidity and mortality, especially among patients undergoing complex procedures such as combined coronary artery bypass grafting (CABG) and valve surgery, Bentall procedures, and open repair of thoracic and thoracoabdominal aortic aneurysms.

\footnotetext{
From the Department of Surgery, ${ }^{\mathrm{a}}$ NUTRIM School for Nutrition, Toxicology and Metabolism, ${ }^{\mathrm{b}}$ and Cardiovascular Research Institute Maastricht (CARIM), ${ }^{\mathrm{c}}$ Maastricht University Medical Center, Maastricht, The Netherlands; and the European Vascular Center Aachen-Maastricht, ${ }^{\mathrm{d}}$ Department of Vascular Surgery, University Hospital Aachen, Aachen, Germany.

I.C.V.W. and S.J.H. contributed equally to this work

Disclosures: Authors have nothing to disclose with regard to commercial support.

Received for publication June 23, 2010; accepted for publication Feb 9, 2011; available ahead of print May 16, 2011.

Address for reprints: Wim A. Buurman, PhD, Department of Surgery, Maastricht University Medical Center, PO Box 616, Maastricht, The Netherlands (E-mail:

w.buurman@maastrichtuniversity.nl).

J Thorac Cardiovasc Surg 2011;142:1-11

0022-5223/\$36.00

Copyright (c) 2011 by The American Association for Thoracic Surgery doi:10.1016/j.jtcvs.2011.02.012
}

These patients are at high risk for development of such major complications as acute kidney injury, ${ }^{1-6}$ pulmonary dysfunction, ${ }^{7,8}$ sepsis, and multiple organ failure. ${ }^{9}$

The pathophysiologic mechanisms underlying these complications have been studied extensively in an attempt to develop specific prevention and treatment strategies. The cardiopulmonary bypass (CPB) circuit has been associated with the development of tissue damage as a result of insufficient oxygen delivery through hemodilution, ${ }^{10}$ ischemia-reperfusion, ${ }^{11}$ and hypoperfusion. ${ }^{12,13}$ Cardiotomy suction during CPB has been shown to be a source of lipid microemboli, which form small vascular occlusions in several tissues, including brain, kidney, spleen, and muscle. ${ }^{14,15}$ Furthermore, the nonendothelial surface of the CPB system initiates a proinflammatory response that deteriorates cellular function, for instance the function of renal tubular cells. ${ }^{16,17}$ Indeed, the use of a mini-CPB system attenuates the release of intestinal and renal tissue damage markers in cardiac surgical patients relative to a normal CPB circuit by reducing both the proinflammatory contact surface area and hemodilution. ${ }^{18}$ Similarly, the incidences of liver injury and kidney injury are significantly reduced in patients undergoing $\mathrm{CABG}$ without $\mathrm{CPB}$ (off-pump CABG) relative to those undergoing on-pump CABG. ${ }^{19,20}$ Nevertheless, although off-pump surgery has gained popularity worldwide, CPB-assisted surgery is still widely used. To reduce CPB-related morbidity and mortality, successful efforts have been made to increase CPB biocompatibility and flow performance. Unfortunately, these improvements have not led to a significantly decreased incidence of organ dysfunction after cardiovascular surgery. ${ }^{21}$ This relative failure underscores the need for further clarification of underlying pathophysiologic mechanisms of tissue damage and dysfunction in this setting. ${ }^{21}$

A common consequence of CPB is hemolysis, which is generally considered an inevitable but relatively harmless phenomenon. Hemolysis is principally caused by mechanical shear stress within the perfusion circuit and results in the release of hemoglobin into the circulation. ${ }^{22,23}$ The role of this cell-free plasma hemoglobin ( $\mathrm{fHb}$ ) in the development of organ injury has gained increasing interest ever since a direct relationship of hemolysis, impaired vascular function, decreased organ perfusion, and organ dysfunction was reproducibly shown in experimental animal models and in chronic hemolytic diseases in human beings. ${ }^{24,25}$ Most recently, Meyer and colleagues ${ }^{26}$ showed that $\mathrm{fHb}$ arising from hemodialysis-induced hemolysis impairs vascular 


$$
\begin{aligned}
& \text { Abbreviations and Acronyms } \\
& \begin{array}{ll}
\mathrm{CABG} & =\text { coronary artery bypass grafting } \\
\mathrm{CO} & =\text { carbon monoxide } \\
\mathrm{CPB} & =\text { cardiopulmonary bypass } \\
\mathrm{fHb} & =\text { cell-free plasma hemoglobin } \\
\mathrm{HO} & =\text { heme oxygenase } \\
\mathrm{NO} & =\text { nitric oxide } \\
\mathrm{RBC} & =\text { red blood cell } \\
\mathrm{SNO}-\mathrm{Hb} & =\text { S-nitrosylated hemoglobin }
\end{array}
\end{aligned}
$$

function in patients, leading to speculation regarding a role for $\mathrm{fHb}$ in the development of microcirculatory dysfunction during acute and transient hemolysis. ${ }^{27}$ Moreover, the results of Meyer and colleagues ${ }^{26}$ substantiate our own recent findings ${ }^{28}$ that acute hemolysis during major aortic surgery is independently associated with proximal renal tubular damage and postoperative acute kidney injury. We therefore propose that hemolysis is an important but as yet generally unrecognized contributor to the development of organ injury during surgical procedures associated with hemolysis, such as cardiovascular surgery.

The interfering role of $\mathrm{fHb}$ in intravascular nitric oxide (NO) metabolism is believed to play a critical role in the development of microcirculatory impairment, organ damage, and organ dysfunction. ${ }^{24}$ In this review we will therefore discuss (1) the effects of fHb on intravascular NO bioavailability, (2) the role of fHb in the induction of microcirculatory dysfunction and organ damage, (3) the potential sources of fHb during cardiovascular surgery, and (4) therapeutic options to attenuate the consequences of hemolysis during $\mathrm{CPB}$-assisted surgery.

\section{INCREASED PLASMA FREE HEMOGLOBIN PRODUCED BY HEMOLYSIS REDUCES INTRAVASCULAR NITRIC OXIDE BIOAVAILABILITY}

On the intravascular destruction of red blood cells (RBCs), fHb enters the circulation. This fHb either gets bound to haptoglobin or is oxidized to methemoglobin. The hemoglobin-haptoglobin complex is rapidly cleared from the circulation through endocytosis by the surface scavenger receptor CD163, which is expressed on monocytes and tissue macrophages. In this way haptoglobin prevents accumulation of plasma $\mathrm{fHb}$ under physiologic circumstances. ${ }^{29}$ This effect was illustrated in patients undergoing cardiac surgery in whom intravenous administration of haptoglobin significantly reduced circulating fHb levels. ${ }^{30}$ Free heme, another byproduct of hemolysis, is released during oxidation of free hemoglobin and is scavenged by circulating hemopexin. Subsequently, heme oxygenase (HO)-1, activated as a result of reduced microcirculation, degrades heme to carbon monoxide
(CO), biliverdin, and iron, mainly in the liver and spleen. ${ }^{31}$ This cytoprotective induction of HO-1 by the microvasculature has been shown to modulate inflammation in patients after cardiac surgery with CPB, which may benefit patient recovery postoperatively ${ }^{32}$; furthermore, the induction of HO-1 inhibits vascular inflammation and vasoocclusion in transgenic sickle cell mice. ${ }^{32,33}$ Because both haptoglobin and hemopexin are not recycled after clearance of hemoglobin-haptoglobin or heme-hemopexin complexes, excessive RBC lysis rapidly exhausts their storage pools. This results in enhanced levels of fHb and free heme, both harmful products. First of all, free heme is able to react with endogenous hydrogen peroxide, thereby forming toxic free radicals that are involved in the induction of prooxidant damage. ${ }^{34}$ Second, oxygenated $\mathrm{fHb}$ has been shown to be a potent scavenger of NO, the most important endogenous vasodilator. The fast $(6-8 \times$ $\left.10^{7} \mathrm{~mol} /[\mathrm{L} \cdot \mathrm{s}]\right)$ and irreversible reaction of oxygenated $\mathrm{fHb}$ with $\mathrm{NO}$ results in conversion of $\mathrm{fHb}$ to methemoglobin and conversion of $\mathrm{NO}$ to nitrate. Circulating $\mathrm{fHb}$ is also present in a deoxygenated form. Such deoxygenated $\mathrm{fHb}$ also scavenges NO, forming nitrosyl hemoglobin, but this reaction is both slower $\left(10^{7} \mathrm{~mol} /[\mathrm{L} \cdot \mathrm{s}]\right)$ and reversible. ${ }^{24,29}$ As a result, hemolysis significantly impairs NO bioavailability, potentially inducing microcirculatory dysfunction. ${ }^{35,36}$ In an in vivo canine hemolysis model, fHb-associated NO scavenging has been found to be correlated with systemic vasoconstriction and a reduction in renal function. ${ }^{25}$ In patients with chronic high $\mathrm{fHb}$ levels as a result of sickle cell disease, forearm blood flow responses were reduced by $80 \%$ after infusion of the NO donor sodium nitroprusside relative to patients with below average $\mathrm{fHb}$ levels. ${ }^{24}$ Third, hemolysis also results in release of arginase 1, an enzyme that converts L-arginine, the substrate for NO synthesis, to ornithine.$^{37}$ In this way, hemolysis not only causes scavenging of NO but also theoretically prevents new NO formation. In practice, however, we have shown that arginase 1 release during surgery with CPB does not affect the arginine to ornithine ratio (unpublished data). This implies that arginase levels during this type of surgery are not high enough to affect arginine levels and thus attenuate NO synthesis. ${ }^{38}$

\section{CELL-FREE HEMOGLOBIN CONTRIBUTES TO MICROCIRCULATORY DYSFUNCTION THROUGH NITRIC OXIDE SCAVENGING, POTENTIALLY INDUCING HYPOXIC TISSUE DAMAGE}

The role of hemolysis in organ damage development had already been described in the mid 1970s. ${ }^{24,39}$ These studies focused on acute kidney injury because glomerularly filtered urinary $\mathrm{fHb}$, rather than plasma $\mathrm{fHb}$, was considered the culprit in organ injury induction. At that time, only the kidney was believed to be at risk for 
fHb-induced damage. Two mechanisms were proposed to underlie the association between hemolysis and renal tissue damage development. First, urinary fHb-derived free iron and heme catalyze the generation of reactive oxygen species, which damage the renal tubular epithelium. ${ }^{40}$ Indeed, administration of the iron scavenger deferoxamine did attenuate glomerular and tubular dysfunction induced by intravenous $\mathrm{fHb}$ administration in rats. ${ }^{41}$ Similarly, a reduced intravascular iron scavenging capacity—reflected by low plasma ferritin concentrations-was associated with acute kidney injury after human cardiovascular surgery. ${ }^{42}$ Second, intratubular fHb precipitation and heme cast formation in the acidic ultrafiltrate were considered to obstruct the tubular lumen, reducing glomerular filtration. ${ }^{40,43}$ Subsequent prevention of cast formation by urinary alkalanization was found to reduce tubular injury and glomerular dysfunction after intravenous $\mathrm{fHb}$ infusion in rats. ${ }^{40}$

The discovery of the NO-scavenging properties of circulating plasma $\mathrm{fHb}$ by Reiter and coworkers ${ }^{24}$ in 2002 provided a complementary explanation for hemolysisinduced organ injury. For the first time, circulating fHb was recognized as a key player in the pathophysiologic mechanisms of complications in patients with chronic hemolytic disorders, such as sickle cell disease and malaria infection. ${ }^{24}$ Furthermore, the reported adverse effects associated with administration of a hemoglobin-based oxygen carrier-which basically consisted of $\mathrm{fHb}$ - could be explained by intravascular NO scavenging through $\mathrm{fHb}^{44}$ The negative effects of increased plasma $\mathrm{fHb}$ have been confirmed by many studies since 2002 in both animals and patients. For example, hemolysis induced by water infusion or direct intravascular $\mathrm{fHb}$ administration in dogs was associated with a significant increase in plasma NO consumption and with simultaneous enhanced systemic vascular resistance. These effects were attenuated by NO inhalation (which causes conversion of plasma $\mathrm{fHb}$ into the less bioactive molecule methemoglobin in the pulmonary circulation), supporting a causal role for NO scavenging by $\mathrm{fHb}^{25}$ In human beings, forearm blood flow responses to intra-arterial infusion of sodium nitroprusside, a NO donor, were found to be negatively correlated with plasma $\mathrm{fHb}$ levels in patients with sickle cell disease. $^{24,25}$

The potential role of plasma $\mathrm{fHb}$ in the development of organ injury is further supported by our observation that plasma $\mathrm{fHb}$ levels are significantly associated with renal proximal tubular damage during CPB-assisted major aortic surgery. ${ }^{26}$ Moreover, peak plasma fHb levels significantly predict postoperative acute kidney injury. We could not detect $\mathrm{fHb}$ in urinary samples during the perioperative period, indicating that urinary $\mathrm{fHb}$ is not a major contributor to renal tubular injury development in this setting. ${ }^{26}$ Also, forearm blood flow responses after infusion of sodium nitroprusside at the time of peak plasma $\mathrm{fHb}$ concentrations are significantly reduced relative to the response measured when fHb-levels are normalized. This observation further underscores a potential causal role of $\mathrm{fHb}$-induced tissue perfusion impairment during surgery (unpublished data). In addition, we have shown that $\mathrm{fHb}$ induces intestinal microcirculatory dysfunction and tissue integrity loss in a rat hemolysis model. ${ }^{45}$

\section{SOURCES OF CIRCULATING FREE HEMOGLOBIN DURING CARDIOVASCULAR SURGERY WITH CARDIOPULMONARY BYPASS}

Hemolysis can principally be attributed to 3 sources during cardiovascular surgery: the $\mathrm{CPB}$, the cell salvage system, and (massive) RBC transfusion.

\section{Cardiopulmonary Bypass}

CPB inflicts sublethal to lethal RBC damage through turbulence and shear stress within the pump, tubes, connectors, cannula, reservoirs, and oxygenator. ${ }^{23}$ Blood-air contact, blood-nonendothelial surface contact, wall impact forces, the use of positive and negative pressures to assist venous drainage, and the use of an integrated cardiotomy suction reservoir all contribute to intraoperative hemolysis. ${ }^{23,46,47}$ In addition to $\mathrm{CPB}$ composition, $\mathrm{CPB}$ duration is considered to influence the degree of hemolysis, with longer CPB times resulting in increased lysis of RBCs. ${ }^{48}$ As evidence of this phenomenon, we found a positive and statistically significant correlation between total fHb release in the perioperative period and the duration of $\mathrm{CPB}$ in a group of 54 patients undergoing CPB-assisted major aortic surgery (unpublished data; Figure 1). In addition to direct $\mathrm{RBC}$ lysis, the CPB system induces sublethal RBC injury. ${ }^{49,50}$ Such sublethally damaged RBCs have been shown to be more prone to later lysis in vivo. ${ }^{23,51}$ Delayed lysis of sublethally damaged RBCs could explain the continuing increase of plasma $\mathrm{fHb}$ after the cessation of $\mathrm{CPB}$ in these patients (unpublished data; Figure 2).

\section{Cell Salvage}

Cell salvage devices are additional sources of $\mathrm{fHb}{ }^{52,53}$ The mechanical trauma of washing and the transfusion of damaged autologous shed blood could contribute to increased plasma fHb levels. Although modern cell salvage systems are able to remove the majority of $\mathrm{fHb}$ during washing, they do not select between intact RBCs and damaged RBCs, which are prone to later lysis in vivo. ${ }^{54}$ In this way, autologous blood transfusion could contribute to increased plasma fHb levels during surgery.

\section{RBC Transfusion}

A last potential source of $\mathrm{fHb}$ is stored $\mathrm{RBC}$ concentrate. Storage of erythrocytes results in irreversible morphologic changes, such as reductions in membrane deformability, 


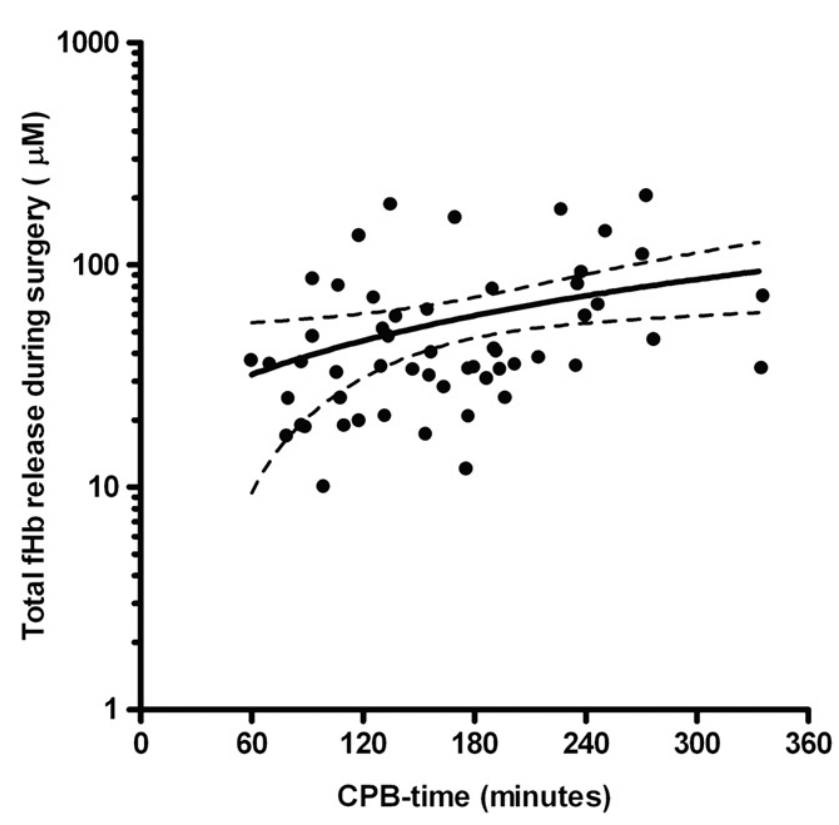

FIGURE 1. Association between cardiopulmonary bypass time and extent of hemolysis. A correlation analysis between cardiopulmonary bypass $(C P B)$ time and total free hemoglobin $(\mathrm{fH} b)$ release (defined as the area under the curve) was performed in 54 patients undergoing open surgical repair of thoracoabdominal aortic aneurysms with cardiopulmonary bypass. A significant correlation (Pearson $r=0.33, P<.05$ ) was found between cardiopulmonary bypass time and plasma free hemoglobin release (unpublished data).

oxygen binding, and delivery capacity, in addition to increased adhesiveness, increased aggregability, and accumulation of proinflammatory substances. ${ }^{55}$ These changes are considered to underlie the relationship between RBC transfusion and adverse outcome, a phenomenon that has given rise to debate about the pros and cons of allogeneic $\mathrm{RBC}$ administration. In addition, the storage duration of blood products appears to be a critical factor in transfusionrelated morbidity and mortality. In a study by Kock and colleagues, ${ }^{55}$ transfusion of "old" blood (stored for $>14$ days) was associated with a significantly higher mortality among patients undergoing cardiac surgery than was seen with transfusion of RBCs stored for 14 days or less. Transfusion of "older" blood was also significantly related to prolonged ventilatory support and increased incidences of renal failure, septicemia or sepsis, and multiple organ failure. In another study, RBC transfusion was the most reliable predictor of adverse outcome in 11,963 patients undergoing isolated $\mathrm{CABG}$, with postoperative morbidity and mortality being dose dependently related to RBC transfusion. ${ }^{56} \mathrm{We}$ propose that high $\mathrm{fHb}$ concentrations caused by RBC lysis in stored blood contribute to posttransfusion morbidity and mortality by inducing microcirculatory dysfunction through NO scavenging. In addition, the shear stress imposed on less viable RBCs within the transfusate could cause additional increases in $\mathrm{fHb}$ both during and after infusion. To study

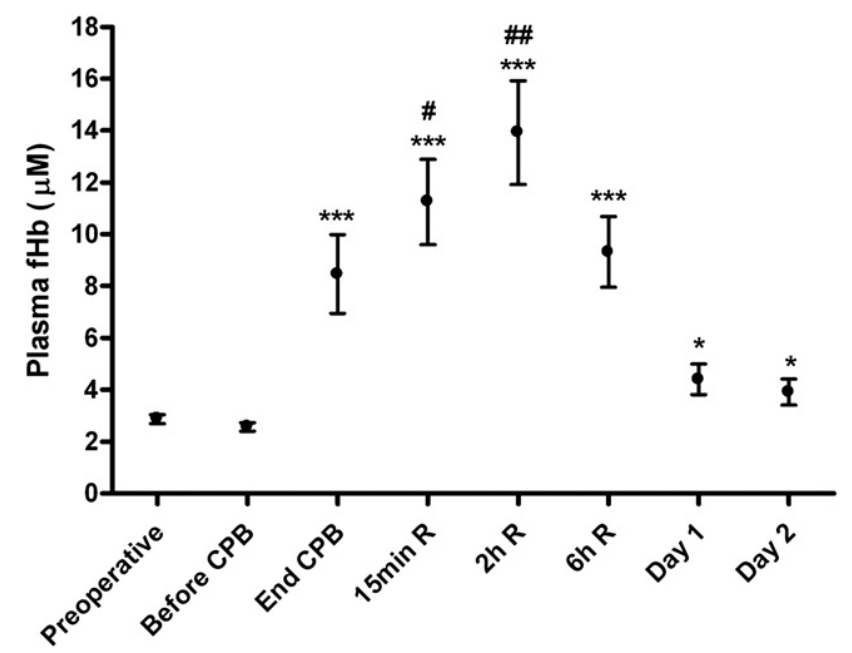

FIGURE 2. Hemolysis during open surgical repair of thoracoabdominal aortic aneurysms with cardiopulmonary bypass $(C P B)$. Plasma free hemoglobin $(\mathrm{fHb})$ levels increased during surgery and continued to increase significantly in the early postoperative period. This indicates ongoing lysis of red blood cells after cardiopulmonary bypass had stopped. Asterisk indicates $P<.05$ versus preoperative level; triple asterisk indicates $P<.001$ versus preoperative level; crosshatch indicates $P<.05$ versus end-CPB level; double crosshatch indicates $P<.01$ versus end-CPB level (unpublished data). $R$, Reperfusion.

the degree of direct hemolysis of packed RBCs, we measured $\mathrm{fHb}$ levels by derivate spectrophotometry ${ }^{57}$ in samples from 60 randomly collected and transfused packed RBC units $(330 \mathrm{~mL} / \mathrm{U})$. The levels of $\mathrm{fHb}$ in the packed RBC supernatant averaged $36 \pm 2 \mu \mathrm{mol} / \mathrm{L}$ (mean \pm SEM), indicating severe hemolysis. Moreover, storage durations and $\mathrm{fHb}$ levels were significantly correlated (unpublished data, Figure 3). This correlation means that transfusion of especially aged packed RBCs can result in an additional increase in circulating $\mathrm{fHb}$ in patients undergoing cardiovascular surgery with CPB. Recently, it was reported that packed RBC transfusion did indeed contribute to systemic fHb levels, with an increase of $7.5 \mu \mathrm{M}$ per transfused unit. ${ }^{58}$ Importantly, the supernatant of the packed RBCs, which contains the $\mathrm{fHb}$ molecules, was indeed able to consume $\mathrm{NO}$, with a strong correlation between $\mathrm{fHb}$ levels and NO consumption. ${ }^{58}$ The contributing effect of RBC transfusion to circulating plasma $\mathrm{fHb}$ concentrations may thus be considerable. The median transfusion requirement in a large cohort of cardiac surgical patients was found to be 2 packed RBC units, ${ }^{55}$ whereas 10 units are required for patients undergoing open repair of thoracoabdominal aortic aneurysms. ${ }^{28}$ Transfusion of 2 or 10 packed RBC units could increase plasma fHb levels, with $15 \mu \mathrm{mol} / \mathrm{L}$ and $75 \mu \mathrm{mol} / \mathrm{L}$, respectively. These levels are in sharp contrast to the plasma fHb levels of 0.1 to 0.2 $\mu \mathrm{mol} / \mathrm{L}$ seen in normal healthy volunteers. ${ }^{24,58}$ In addition to direct $\mathrm{fHb}$ administration through packed $\mathrm{RBC}$ 


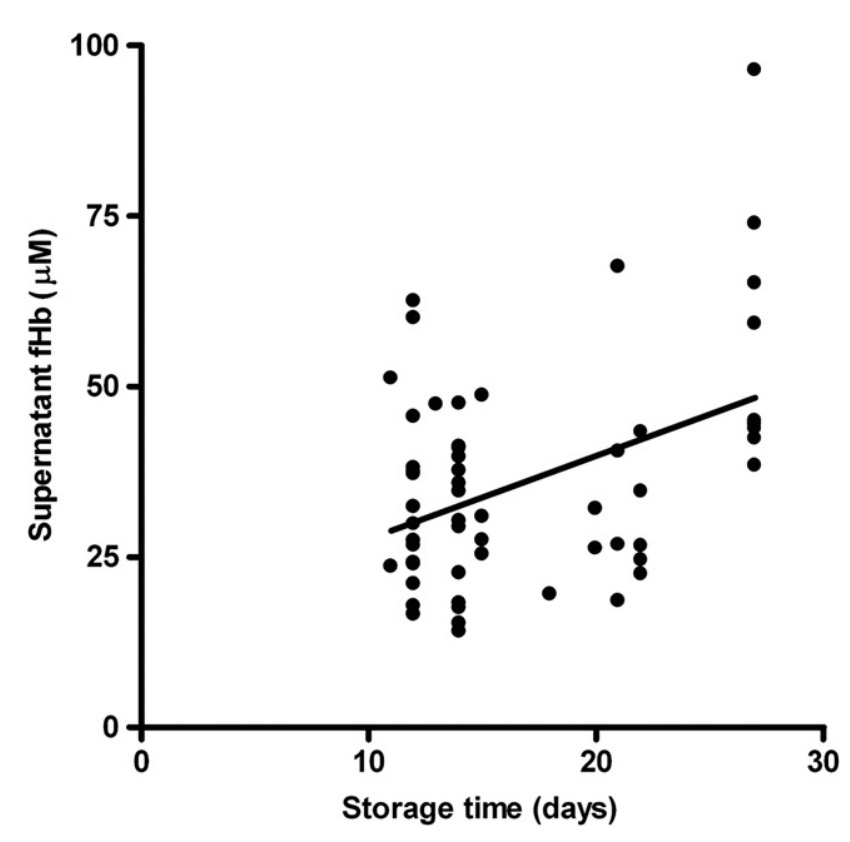

FIGURE 3. Association between storage time and free hemoglobin $(f H b)$ levels in packed red blood cell transfusion bags. A significant correlation (Pearson $r=0.43, P<.001$ ) was found between packed red blood cell storage duration and free hemoglobin concentration in packed red blood cell transfusion bags $(\mathrm{n}=60)$ used for transfusion during cardiovascular surgery. These data indicate that prolonged storage duration results in more red blood cell injury, with concomitantly more free hemoglobin being transfused into the patient (unpublished data).

transfusion, systemic $\mathrm{fHb}$ concentrations could additionally increase as a result of delayed lysis of sublethally damaged RBCs. Finally, another consequence of RBC storage is that NO bound to intracellular hemoglobin, known as S-nitrosylated hemoglobin (SNO-Hb), is rapidly depleted. $\mathrm{RBCs}$ containing SNO-Hb are believed to contribute to vasodilation under hypoxic conditions through release of NO. Indeed, the capacity of RBCs to induce vasodilation is significantly diminished in parallel with $\mathrm{SNO}-\mathrm{Hb}$ depletion. In a canine study, reconstitution of SNO-Hb by exposure to aqueous NO restored the vasodilatory capacity of transfused RBCs and improved cardiac blood flow. ${ }^{59}$

\section{THERAPEUTIC OPTIONS TO ATTENUATE THE ADVERSE EFFECTS OF CELL-FREE PLASMA HEMOGLOBIN-MEDIATED NITRIC OXIDE SCAVENGING}

The discovery of the NO-scavenging capacity of circulating $\mathrm{fHb}$ opened up a new field of study regarding therapeutic options in diseases characterized by chronic hemolysis, such as sickle cell disease and malaria. ${ }^{60}$ In this section, we present therapies that we consider to be of value for patients with acute hemolytic episodes, such as occur during cardiovascular surgery (Table 1$)$.

The direct (intravascular) therapeutic use of NO itself is greatly impeded by its extremely short half-life of 0.05 to
$1.8 \mathrm{~ms}$ in vivo. ${ }^{61}$ Therefore either inactivation of $\mathrm{fHb}$ or enhancement of the NO-donor pool has the potential to reduce the incidence and severity of complications of hemolytic diseases. We focus mainly on 3 potential therapeutic interventions (Figure 4): NO inhalation, nitrite supplementation, and haptoglobin administration. We consider these therapeutic options to be the most clinically relevant at this time. In addition, we discuss 3 more experimental therapies: arginine and citrulline supplementation, $\mathrm{CO}$ inhalation, and endothelin receptor blockade. For a more complete discussion of therapeutic options in chronic hemolytic disease, we refer the reader to articles by Kato and Gladwin ${ }^{60}$ and Lundberg and colleagues. $^{62}$

\section{NO Inhalation}

Intravascular conversion of plasma fHb into a less bioactive molecule is an interesting option to reduce the adverse consequences of increased $\mathrm{fHb}$ concentrations. NO gas inhalation results in pulmonary oxidation of $\mathrm{fHb}$ into methemoglobin, which does not scavenge NO, reducing NO consumption in plasma. In a canine hemolysis model, NO inhalation attenuated the pulmonary and systemic vasoconstrictor effects of $\mathrm{fHb}^{25}$ In patients with sickle cell disease, NO inhalation of $80 \mathrm{ppm}$ for 1.5 hours reduced pain during vasoocclusive crisis, diminished plasma NO consumption, and increased methemoglobin levels, indicating oxidation of $\mathrm{fHb}^{24}$ Moreover, inhalation of $\mathrm{NO}$ at 80 ppm for 4 hours in children with sickle cell disease was not associated with any toxic side effects, such as hypotension, clinically significant decreases in oxygenation by pulse oximetry, significant increases in methemoglobin, or toxic concentrations of nitrogen dioxide. ${ }^{63}$ Even continuous $\mathrm{NO}$ inhalation at $40 \mathrm{ppm}$ for 3.2 days in a patient with sickle cell disease with multiorgan involvement was not associated with adverse side effects and it markedly improved the patient's clinical state. ${ }^{64}$ Finally, mixing of $\mathrm{NO}$ gas at concentrations as great as $20 \mathrm{ppm}$ with normal ventilation gas showed therapeutic potential in adult patients with cardiac surgery-associated pulmonary hypertension by reducing right ventricular afterload and preventing right ventricular failure. ${ }^{65,66}$ In addition to $\mathrm{fHb}$ oxidation, NO gas inhalation also results in the formation of relatively stable NO species in the lung. Longer intravascular half-lives of these NO carriers, such as nitrite, enable transport of NO in the blood, mediating extrapulmonary effects of $\mathrm{NO}$ gas inhalation. ${ }^{67,68}$ In conclusion, we consider NO inhalation to be a promising and potentially easily applicable therapeutic option to attenuate the adverse effects of fHb-mediated NO scavenging during cardiovascular surgery. Ideally, the dose of NO inhalation could even be adjusted according to intraoperative fHb measurements, which are already routinely performed at our institution. 
TABLE 1. Potential therapeutic options to reduce hemolysis-associated morbidity in patients undergoing cardiovascular surgery

\begin{tabular}{|c|c|c|c|}
\hline Therapy & Main therapeutic mechanisms & Feasibility & References \\
\hline NO inhalation & $\begin{array}{l}\text { Oxidizes and inactivates } \mathrm{fHb} \text { in pulmonary } \\
\text { circulation, reducing NO scavenging } \\
\text { Stimulates intrapulmonary } \\
\text { formation of NO } \\
\text { donors, enhancing NO } \\
\text { bioavailability }\end{array}$ & $\begin{array}{l}\text { Already applied in patients } \\
\text { with sickle cell disease and those } \\
\text { undergoing } \\
\text { cardiac surgery } \\
\text { Exact dose and duration of } \\
\text { inhalation need to be } \\
\text { studied }\end{array}$ & $\begin{array}{l}\text { Reiter et al, } \\
\text { Minneci et al, } \\
\text { Kato et al, } \\
\text { Cannon et al } \\
{ }^{67}\end{array}$ \\
\hline $\begin{array}{l}\text { Nitrite supplementation } \\
\text { (oral, intravenously, } \\
\text { by inhalation) }\end{array}$ & $\begin{array}{l}\text { NO donor during reduction, } \\
\text { especially during hypoxia } \\
\text { and low pH } \\
\text { Mediates cytoprotection through hypoxic } \\
\text { vasodilation and decreased formation } \\
\text { of reactive oxygen species } \\
\text { Oxidizes fHb, thereby } \\
\text { reducing NO scavenging }\end{array}$ & $\begin{array}{l}\text { Nitrite successfully used in } \\
\text { experimental setting with } \\
\text { patients with sickle cell disease } \\
\text { Exact dose, duration, and mode of } \\
\text { administration need to be assessed }\end{array}$ & $\begin{array}{l}\text { Lundberg et al, } \\
\text { Shiva et al, } \\
\text { Piknova et al, } \\
\text { Minneci et al }^{76}\end{array}$ \\
\hline Haptoglobin administration & $\begin{array}{l}\text { Natural } \mathrm{fHb} \text { scavenger } \\
\text { Accelerates fHb uptake by monocytes and } \\
\text { macrophages and accelerates } \\
\text { hepatic degradation } \\
\text { Limits renal filtration of } \mathrm{fHb}\end{array}$ & $\begin{array}{l}\text { Costs currently limit } \\
\text { clinical applicability } \\
\text { Haptoglobin potentially does not limit } \\
\text { NO scavenging by fHb }\end{array}$ & $\begin{array}{l}\text { Tanaka et al, } \\
\text { Lim et al, } \\
\text { Azarov et al, } \\
\text { Boretti et al }\end{array}$ \\
\hline $\begin{array}{l}\text { Arginine and citrulline } \\
\text { supplementation }\end{array}$ & $\begin{array}{l}\text { Enhances substrate delivery for NO } \\
\text { formation through nitric oxide } \\
\text { synthases }\end{array}$ & $\begin{array}{l}\text { Arginine used experimentally in } 10 \text { patients } \\
\text { with sickle cell disease } \\
\text { Dose and duration of arginine and citrulline } \\
\text { administration unknown }\end{array}$ & $\begin{array}{l}\text { Morris et al, } \\
\quad \text { Luiking et al }\end{array}$ \\
\hline Carbon monoxide inhalation & $\begin{array}{l}\text { Regulates vascular tone and } \\
\text { induces vasodilation at low doses } \\
\text { Reduces proinflammatory } \\
\text { response } \\
\text { Relatively inert and does not form reactive } \\
\text { oxygen species }\end{array}$ & $\begin{array}{l}\text { No human data on applicability in setting } \\
\text { of cardiovascular surgery }\end{array}$ & Belcher et $\mathrm{al}^{33}$ \\
\hline Endothelin receptor blockade & $\begin{array}{l}\text { Limits endothelin } 1 \text {-induced } \\
\text { vasoconstriction }\end{array}$ & $\begin{array}{l}\text { Only tested in mouse sickle cell disease } \\
\text { model }\end{array}$ & Sabaa et $\mathrm{al}^{90}$ \\
\hline
\end{tabular}

NO, Nitric oxide; $f H b$, free hemoglobin.

\section{Nitrite Supplementation}

Another promising candidate for therapeutic use is the nitrite anion $\left(\mathrm{NO}_{2}{ }^{-}\right)$, long believed to be merely an inert oxidation product of NO. Recent studies, however, have provided evidence for the existence of multiple nitrite reducing pathways in which nitrite is converted back to NO, making nitrite an important NO donor. ${ }^{62,69,70}$ Furthermore, nitrite is able to oxidize $\mathrm{fHb}$ in plasma, potentially limiting the capacity of $\mathrm{fHb}$ to scavenge $\mathrm{NO}^{71}$ The enzymatic and nonenzymatic pathways of nitrite reduction include (free) deoxyhemoglobin and deoxymyoglobin, xanthine oxidoreductase, protons, ascorbate, and polyphenols. ${ }^{62}$ The process of NO reduction is most efficient at low $\mathrm{PO}_{2}$ and low $\mathrm{pH}$ and thus occurs preferentially during hypoxia or anoxia. ${ }^{70,72,73}$ This is of particular importance because $\mathrm{NO}$ synthase activity is greatly limited at low $\mathrm{Po}_{2}$ values. ${ }^{74}$ In adult patients with sickle cell anemia, infusions of $0.4-, 4-$, and $40-\mu \mathrm{mol} / \mathrm{L}$ nitrite into the brachial artery led to a dose-dependent increase in forearm blood flow as great as $77 \% .{ }^{75}$ In a canine hemolysis model, sodium nitrite increased blood flow in a similar way. ${ }^{76}$ In addition to promoting vasodilation, nitrite has been shown to exert potent cytoprotective effects in the liver, heart, and brain in several animal models of ischemia-reperfusion. ${ }^{77}$ The pathway by which nitrite mediates cytoprotection in this setting is as yet unresolved but is believed to be dual. First, nitrite enables hypoxic vasodilation, as stated previously. Second, nitrite is able to nitrosate complex I of the mitochondrial electron transport chain, inhibiting its activity and decreasing the formation of reactive oxygen species in the reperfusion phase ${ }^{69}$ Considering these properties, it has been suggested that nitrite has therapeutic value in various diseases, such as sickle cell disease, stroke, myocardial infarction, and organ transplantation. Nevertheless, the optimal nitrite dose for 


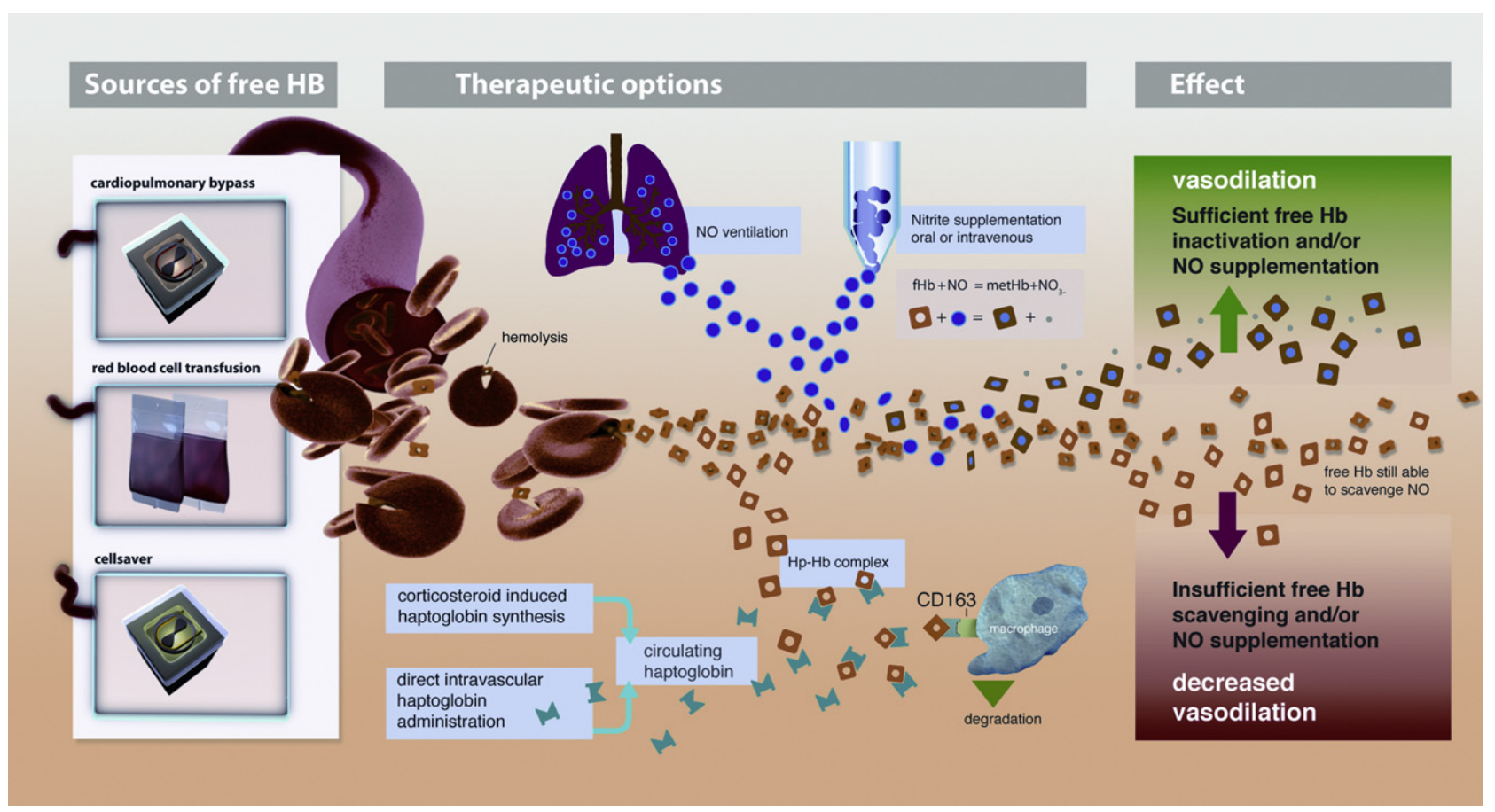

FIGURE 4. Potential sources and effects of plasma free hemoglobin $(H B)$ during cardiovascular surgery with cardiopulmonary bypass, and therapeutic options to attenuate hemolysis-induced organ damage. Intravascular hemolysis during cardiovascular surgery can be attributed to the cardiopulmonary bypass, transfusion of red blood cells, and cell salvage use (left). Lysis of red blood cells results in increased circulating plasma free hemoglobin $(\mathrm{Hb})$ levels (orange squares). Under physiologic conditions, free hemoglobin is rapidly cleared by the scavenger haptoglobin. Haptoglobin-hemoglobin $(\mathrm{Hp}-\mathrm{Hb}) \mathrm{com}-$ plexes bind to CD163 expressed by monocytes and macrophages, initiating endocytosis and degradation (middle, bottom). Haptoglobin is not recycled, so excessive hemolysis depletes haptoglobin storages rapidly. Nonscavenged free hemoglobin $(f H b)$ potently binds circulating nitric oxide $(\mathrm{NO})$, thereby limiting its bioavailability. In this way high free hemoglobin levels increase the nitric oxide-scavenging capacity of blood, causing impaired vasodilation as a result of vascular nitric oxide shortage. Decreased vasodilation contributes to impaired tissue perfusion and development of organ damage and organ dysfunction (right, bottom). The adverse effects of free hemoglobin may be counteracted by either increasing haptoglobin levels to support free hemoglobin scavenging or enhancing the nitric oxide donor pool to increase nitric oxide bioavailability. Haptoglobin can be administered intravenously, or haptoglobin synthesis may be upregulated through corticosteroid administration (center, bottom). The nitric oxide donor pool could be increased by oral or intravenous administration of nitrite, which is oxidized to nitric oxide under low $\mathrm{Po}_{2}$ or low $\mathrm{pH}$. Nitric oxide inhalation inactivates free hemoglobin in the pulmonary circulation (or oxygenator in the cardiopulmonary bypass circuit) by transforming it to bioinactive methemoglobin (metHb, center, top). In this way scavenging and inactivation of free hemoglobin and supplementation of nitric oxide prevent the adverse effects of plasma free hemoglobin during cardiovascular surgery (right, top).

human systemic administration has not yet been clarified. Interestingly, the effect of nitrite may be greater at low plasma concentrations $(<200 \mathrm{nmol} / \mathrm{L})$, being lost at high plasma levels $(>1000 \mu \mathrm{mol} / \mathrm{L}) .^{78,79}$ Furthermore, it has been reported that the reaction between oxygenated $\mathrm{fHb}$ (in contrast to deoxygenated $\mathrm{fHb}$ ) and nitrite could initiate an autocatalytic free radical chain, leading to unwanted oxidative damage. ${ }^{80}$ Piknova and colleagues ${ }^{71}$ addressed this issue and concluded that free radical formation in plasma during the reaction of pharmacologic doses of nitrite (up to $120 \mu \mathrm{mol} / \mathrm{L}$ ) with clinically relevant levels of $\mathrm{fHb}$ (30 $\mu \mathrm{mol} / \mathrm{L}$ ) would be highly unlikely. In conclusion, we consider nitrite to have potential in patients undergoing cardiovascular surgery to prevent and treat hemolysis-associated morbidity. Nevertheless, the optimal dose and application must be studied further.

\section{Haptoglobin Administration}

Administration of haptoglobin, which is the physiologic $\mathrm{fHb}$ scavenger, appears to be a logical choice for reducing $\mathrm{fHb}$ concentrations. Haptoglobin targets $\mathrm{fHb}$ for degradation in the liver, monocytes, and macrophages. Furthermore, haptoglobin prevents glomerular filtration of $\mathrm{fHb}$, reducing fHb-induced kidney damage. Increased fHb levels during cardiac surgery have been associated with total depletion of haptoglobin, ${ }^{30}$ enhancing the NO-scavenging capacity of plasma. Indeed, haptoglobin knock-out mice were found to be more sensitive to the adverse effects of phenylhydrazine-induced hemolysis. ${ }^{81}$ Renal DNA damage was significantly higher and glomerular filtration function (reflected by poorer renal clearance of tritium-labeled inulin) was significantly lower in haptoglobin knock-out mice relative to haptoglobin-positive mice. Interestingly, 
administration of vasodilators restored glomerular filtration, implicating renal vasoconstriction as the major contributor to hemolysis-induced acute kidney injury. This supports the mechanism of NO scavenging by plasma $\mathrm{fHb}$. In addition, haptoglobin administration in patients undergoing cardiac surgery with plasma fHb levels surpassing $2.3 \mu \mathrm{mol} / \mathrm{L}$ was associated with a reduction of renal tubular damage. ${ }^{30}$ Nevertheless, this positive effect of haptoglobin was attributed to a decrease in urinary fHb levels and a subsequent attenuation of oxidative renal damage.

Haptoglobin administration is an interesting therapeutic option, but its clinical application may be limited. First, it has been recently found that in vitro the hemoglobin-haptoglobin complex still potently scavenges $\mathrm{NO}$ at the same rate as $\mathrm{fHb}$. Although binding of $\mathrm{fHb}$ to haptoglobin increases the rate of uptake by monocytes and macrophages 2-fold (hereby disabling NO scavenging), it is questionable whether this increased uptake would affect NO bioavailability. ${ }^{82}$ Second, the costs involved in retrieving or producing the amounts of haptoglobin necessary for clinical application currently limit widespread implementation. Recently, Boretti and coworkers ${ }^{83}$ made use of the fact that the haptoglobin promoter gene contains glucocorticoid-responsive elements. Administration of $4 \mathrm{mg} / \mathrm{kg}$ prednisone twice daily for 3 days increased plasma haptoglobin levels 6-fold in dogs. ${ }^{83}$ Importantly, the glucocorticoid stimulation of haptoglobin synthesis prevented the $\mathrm{fHb}$-induced increase in mean arterial pressure in dogs after $\mathrm{fHb}$ infusion, most probably as a result of scavenging of $\mathrm{fHb}$ by haptoglobin. ${ }^{83}$ This finding sheds new light on the long-standing debate as to whether corticosteroid administration during cardiac and cardiovascular surgery is useful. ${ }^{84,85}$ In summary, haptoglobin could be useful to reduce kidney damage caused by intratubular fHb toxicity. The effect on NO scavenging may, however, be limited.

\section{Other Potential Therapies}

We consider NO inhalation and nitrite supplementation to be promising therapeutic interventions, because both can be used successfully in the acute setting of cardiovascular surgery. Notwithstanding, several other therapeutic modalities may be of value for patients at risk for acute hemolytic episodes.

Arginine and citrulline supplementation. The natural nitrogen donor for $\mathrm{NO}$ synthesis is L-arginine, and arginine supplementation enhances NO formation. Arginine therapy at a dose of $0.1 \mathrm{~g} / \mathrm{kg} 3$ times a day for 5 days in 10 adult patients with sickle cell anemia and pulmonary hypertension resulted in a significant decrease $(15.2 \%)$ in pulmonary arterial systolic pressures, implicating vasodilation. ${ }^{86,87}$

Another interesting approach would be administration of citrulline, a substrate for de novo arginine synthesis. It has been suggested that in cases of high arginase 1 levels, such as occur during hemolysis, citrulline supplementation might restore the intracellular arginine balance and promote NO production. ${ }^{88}$ It remains unknown, however, whether and to what extent arginine or citrulline supplementation is beneficial in patients with acute hemolysis during cardiovascular surgery.

CO inhalation. $\mathrm{CO}$ is produced during breakdown of the heme ring of $\mathrm{fHb}$, which is mediated by HO-1. Inhaled $\mathrm{CO}$, at low doses of $250 \mathrm{ppm}$ or less, has been shown to reduce vasoocclusion in a mouse sickle cell model. $\mathrm{CO}$ even mimics some of the functions of NO, such as inhibition of platelet aggregation and activation, regulation of vascular tone, and reduction of a proinflammatory response. ${ }^{33} \mathrm{CO}$ is relatively inert, in contrast to $\mathrm{NO}$, which is able to react with intravascular reactive oxygen species to form the highly reactive peroxynitrite $\left(\mathrm{ONOO}^{-}\right) .{ }^{89} \mathrm{CO}$ has therefore been proposed to be even more effective in treating hemolytic disease than NO, but this hypothesis has not been substantiated in human studies.

Endothelin receptor blockade. Endothelin 1 is an extremely potent vasoconstrictor, and its secretion is repressed by NO. Diminished NO bioavailability as a result of hemolysis counterbalances this negative feedback, resulting in enhanced endothelin 1 levels and vasoconstriction. A mouse sickle cell model provided evidence for beneficial effects of endothelin receptor blockade on renal blood flow, inflammation, and vascular congestion in the lungs and kidneys. ${ }^{90}$ Reduction of inflammation would be an additional positive effect in patients subjected to $\mathrm{CPB}$, which induces a proinflammatory response. Nevertheless, further studies are essential to determine whether short-term endothelin receptor blockage is beneficial in this setting, because it is very different from sickle cell anemia.

In conclusion, there are several promising therapeutic interventions to attenuate the adverse effects of increased plasma $\mathrm{fHb}$ levels in patients suffering from acute hemolytic disease, including patients undergoing surgery with $\mathrm{CPB}$, patients with trauma, and patients needing longterm extracorporeal support, for instance extracorporeal membrane oxygenation or hemodialysis. ${ }^{91,92}$

\section{HEMOLYSIS-INDUCED ORGAN INJURY IN CARDIOVASCULAR SURGERY: SUMMARY AND FUTURE PERSPECTIVES}

As evaluated in this review, hemolysis during CPB creates a latent adverse effect. The NO-scavenging effect of plasma $\mathrm{fHb}$ contributes to the deleterious effects of $\mathrm{CPB}$, such as hypoperfusion and ischemia-reperfusion, thereby further hampering tissue perfusion and resulting in organ injury and dysfunction. These findings shed new light on the pathophysiologic mechanisms and preventive measures of organ injury during on-pump cardiovascular surgery (Figure 4). 


\section{CONCLUSIONS}

Evidence is mounting that enhanced circulating levels of plasma $\mathrm{fHb}$ are detrimental, not only in the setting of chronic hemolytic diseases but also in the acute setting of cardiovascular surgery. The $\mathrm{fHb}$-induced perturbations in microcirculatory blood flow and subsequent hypoperfusion or even ischemic damage, complemented by urinary $\mathrm{fHb}$-induced oxidative stress to renal tissue cells, should be acknowledged as an important risk factor for organ injury development in patients undergoing cardiovascular surgery. Patients undergoing such procedures are at increased risk for development of postoperative organ injury, with correspondingly worse patient outcomes. Circulating $\mathrm{fHb}$ appears to be an important determinant in organ injury development, which offers a new therapeutic opportunity to reduce postoperative morbidity and mortality of these patients. Interventional studies with NO inhalation, nitrite supplementation, or haptoglobin administration should be performed to establish the causal links among plasma fHb, NO bioavailability, and organ injury in this particular setting. ${ }^{25,30,93,94}$ Furthermore, such interventional studies will provide valuable information for improvement of patient outcome. Finally, the role of $\mathrm{fHb}$ in organ injury development is of importance not only for patients undergoing cardiovascular surgery but also for other patient groups at risk for hemolysis, such as patients with trauma, patients undergoing hemodialysis, and patients requiring long-term extracorporeal oxygenation or extracorporeal life-support.

\section{References}

1. Andersson LG, Ekroth R, Bratteby LE, Hallhagen S, Wesslén O. Acute renal failure after coronary surgery - a study of incidence and risk factors in 2009 consecutive patients. Thorac Cardiovasc Surg. 1993;41:237-41.

2. Conlon PJ, Stafford-Smith M, White WD, Newman MF, King S, Winn MP, et al. Acute renal failure following cardiac surgery. Nephrol Dial Transplant. 1999;14: 1158-62.

3. Grayson AD, Khater M, Jackson M, Fox MA. Valvular heart operation is an independent risk factor for acute renal failure. Ann Thorac Surg. 2003;75: 1829-35.

4. Provenchère S, Plantefève G, Hufnagel G, Vicaut E, De Vaumas C, Lecharny JB, et al. Renal dysfunction after cardiac surgery with normothermic cardiopulmonary bypass: incidence, risk factors, and effect on clinical outcome. Anesth Analg. 2003;96:1258-64, table of contents.

5. Achouh PE, Madsen K, Miller CC 3rd, Estrera AL, Azizzadeh A, Dhareshwar J, et al. Gastrointestinal complications after descending thoracic and thoracoabdominal aortic repairs: a 14-year experience. J Vasc Surg. 2006;44:442-6.

6. Jacobs MJ, de Mol BA, Legemate DA, Veldman DJ, de Haan P, Kalkman CJ. Retrograde aortic and selective organ perfusion during thoracoabdominal aortic aneurysm repair. Eur J Vasc Endovasc Surg. 1997;14:360-6

7. Coselli JS, LeMaire SA, Conklin LD, Köksoy C, Schmittling ZC. Morbidity and mortality after extent II thoracoabdominal aortic aneurysm repair. Ann Thorac Surg. 2002;73:1107-16

8. Rectenwald JE, Huber TS, Martin TD, Ozaki CK, Devidas M, Welborn MB, et al. Functional outcome after thoracoabdominal aortic aneurysm repair. $J$ Vasc Surg. 2002;35:640-7.

9. Kieffer E, Chiche L, Godet G, Koskas F, Bahnini A, Bertrand M, et al. Type IV thoracoabdominal aneurysm repair: predictors of postoperative mortality, spinal cord injury, and acute intestinal ischemia. Ann Vasc Surg. 2008;22:822-8.

10. Vermeer H, Teerenstra S, de Sévaux RG, van Swieten HA, Weerwind PW. The effect of hemodilution during normothermic cardiac surgery on renal physiology and function: a review. Perfusion. 2008;23:329-38.
11. Fink MP. Thoracoabdominal aortic aneurysm repair: a human model of ischemia/ reperfusion-induced cytokine-driven multiple organ dysfunction syndrome. Crit Care Med. 2000;28:3356-7

12. Leijdekkers VJ, Wirds JW, Vahl AC, van Genderingen HR, Siebenga J, Westerhof $\mathrm{N}$, et al. The visceral perfusion system and distal bypass during thoracoabdominal aneurysm surgery: an alternative for physiological blood flow? Cardiovasc Surg. 1999;7:219-24.

13. Kuttila K, Niinikoski J, Haglund U. Visceral and peripheral tissue perfusion after cardiac surgery. Scand J Thorac Cardiovasc Surg. 1991;25:57-62.

14. Brooker RF, Brown WR, Moody DM, Hammon JW Jr, Reboussin DM, Deal DD, et al. Cardiotomy suction: a major source of brain lipid emboli during cardiopulmonary bypass. Ann Thorac Surg. 1998;65:1651-5.

15. Brondén B, Dencker M, Allers M, Plaza I, Jönsson H. Differential distribution of lipid microemboli after cardiac surgery. Ann Thorac Surg. 2006;81:643-8.

16. Hanssen SJ, Derikx JP, Vermeulen Windsant IC, Heijmans JH, Koeppel TA Schurink GW, et al. Visceral injury and systemic inflammation in patients undergoing extracorporeal circulation during aortic surgery. Ann Surg. 2008;248: 117-25. Erratum in: Ann Surg. 2010;251:187.

17. Rosner MH, Okusa MD. Acute kidney injury associated with cardiac surgery. Clin J Am Soc Nephrol. 2006;1:19-32.

18. Huybregts RA, Morariu AM, Rakhorst G, Spiegelenberg SR, Romijn HW, de Vroege R, et al. Attenuated renal and intestinal injury after use of a minicardiopulmonary bypass system. Ann Thorac Surg. 2007;83:1760-6.

19. Yamada T, Ochiai R, Takeda J, Kikuchi H, Ishibashi M, Watanabe K. Off-pump coronary artery bypass attenuates transient hepatocellular damage after myocardial revascularization. J Cardiothorac Vasc Anesth. 2005;19:603-7.

20. Nigwekar SU, Kandula P, Hix JK, Thakar CV. Off-pump coronary artery bypass surgery and acute kidney injury: a meta-analysis of randomized and observational studies. Am J Kidney Dis. 2009;54:413-23.

21. Kelly KJ, Molitoris BA. Acute renal failure in the new millennium: time to consider combination therapy. Semin Nephrol. 2000;20:4-19.

22. Fransen EJ, Ganushchak YM, Vijay V, de Jong DS, Buurman WA, Maessen JG. Evaluation of a new condensed extra-corporeal circuit for cardiac surgery: a prospective randomized clinical pilot study. Perfusion. 2005;20:91-9.

23. Vercaemst L. Hemolysis in cardiac surgery patients undergoing cardiopulmonary bypass: a review in search of a treatment algorithm. $J$ Extra Corpor Technol. 2008;40:257-67.

24. Reiter CD, Wang X, Tanus-Santos JE, Hogg N, Cannon RO 3rd, Schechter AN et al. Cell-free hemoglobin limits nitric oxide bioavailability in sickle-cell disease. Nat Med. 2002;8:1383-9.

25. Minneci PC, Deans KJ, Zhi H, Yuen PS, Star RA, Banks SM, et al. Hemolysisassociated endothelial dysfunction mediated by accelerated NO inactivation by decompartmentalized oxyhemoglobin. J Clin Invest. 2005;115:3409-17.

26. Meyer C, Heiss C, Drexhage C, Kehmeier ES, Balzer J, Mühlfeld A, et al. Hemodialysis-induced release of hemoglobin limits nitric oxide bioavailability and impairs vascular function. J Am Coll Cardiol. 2010;55:454-9.

27. Donadee CL, Gladwin MT. Hemodialysis hyperhemolysis. A novel mechanism of endothelial dysfunction and cardiovascular risk? J Am Coll Cardiol. 2010;55: 460-2.

28. Vermeulen Windsant IC, Snoeijs MG, Hanssen SJ, Altintas S, Heijmans JH Koeppel TA, et al. Hemolysis is associated with acute kidney injury during major aortic surgery. Kidney Int. 2010;77:913-20.

29. Rother RP, Bell L, Hillmen P, Gladwin MT. The clinical sequelae of intravascular hemolysis and extracellular plasma hemoglobin: a novel mechanism of human disease. JAMA. 2005;293:1653-62.

30. Tanaka K, Kanamori Y, Sato T, Kondo C, Katayama Y, Yada I, et al. Administration of haptoglobin during cardiopulmonary bypass surgery. ASAIO Trans. 1991 37:M482-3.

31. Maines MD. The heme oxygenase system: a regulator of second messenge gases. Annu Rev Pharmacol Toxicol. 1997;37:517-54.

32. Philippidis P, Mason JC, Evans BJ, Nadra I, Taylor KM, Haskard DO, et al. Hemoglobin scavenger receptor CD163 mediates interleukin-10 release and heme oxygenase-1 synthesis: antiinflammatory monocyte-macrophage responses in vitro, in resolving skin blisters in vivo, and after cardiopulmonary bypass surgery. Circ Res. 2004;94:119-26.

33. Belcher JD, Mahaseth H, Welch TE, Otterbein LE, Hebbel RP, Vercellotti GM Heme oxygenase- 1 is a modulator of inflammation and vaso-occlusion in transgenic sickle mice. J Clin Invest. 2006;116:808-16.

34. Kristiansen M, Graversen JH, Jacobsen C, Sonne O, Hoffman HJ, Law SK, et al Identification of the haemoglobin scavenger receptor. Nature. 2001;409. 198-201. 
35. Liao JC, Hein TW, Vaughn MW, Huang KT, Kuo L. Intravascular flow decreases erythrocyte consumption of nitric oxide. Proc Natl Acad Sci U S A. 1999;96: 8757-61.

36. Vaughn MW, Huang KT, Kuo L, Liao JC. Erythrocytes possess an intrinsic barrier to nitric oxide consumption. J Biol Chem. 2000;275:2342-8.

37. Morris CR, Kato GJ, Poljakovic M, Wang X, Blackwelder WC, Sachdev V, et al. Dysregulated arginine metabolism, hemolysis-associated pulmonary hypertension, and mortality in sickle cell disease. JAMA. 2005;294:81-90.

38. van de Poll MC, Hanssen SJ, Berbée M, Deutz NE, Monbaliu D, Buurman WA et al. Elevated plasma arginase-1 does not affect plasma arginine in patients undergoing liver resection. Clin Sci (Lond). 2008;114:231-41.

39. Burck HC, Diekman MA, Sedlaczek T. [Acute renal failure after the infusion of hemoglobin solutions with or without red cell ghosts in rabbits]. Res Exp Med. 1975;166:79-84. German.

40. Zager RA, Gamelin LM. Pathogenetic mechanisms in experimental hemoglobinuric acute renal failure. Am J Physiol. 1989;256(3 Pt 2):F446-55.

41. Paller MS. Hemoglobin- and myoglobin-induced acute renal failure in rats: role of iron in nephrotoxicity. Am J Physiol. 1988;255(3 Pt 2):F539-44.

42. Davis CL, Kausz AT, Zager RA, Kharasch ED, Cochran RP. Acute renal failure after cardiopulmonary bypass in related to decreased serum ferritin levels. J Am Soc Nephrol. 1999;10:2396-402.

43. Everse J, Hsia N. The toxicities of native and modified hemoglobins. Free Radic Biol Med. 1997;22:1075-99.

44. Natanson C, Kern SJ, Lurie P, Banks SM, Wolfe SM. Cell-free hemoglobin-based blood substitutes and risk of myocardial infarction and death: a meta-analysis. JAMA. 2008;299:2304-12. Erratum in: JAMA. 2008;300:1300.

45. Hanssen SJ, Lubbers T, Hodin CM, Prinzen FW, Buurman WA, Jacobs MJ. Hemolysis results in impaired intestinal microcirculation and intestinal epithelial cell injury. World J Gastroenterol. 2011;17:213-8.

46. Fabre O, Vincentelli A, Corseaux D, Juthier F, Susen S, Bauters A, et al. Comparison of blood activation in the wound, active vent, and cardiopulmonary bypass circuit. Ann Thorac Surg. 2008;86:537-41.

47. Mulholland JW, Massey W, Shelton JC. Investigation and quantification of the blood trauma caused by the combined dynamic forces experienced during cardiopulmonary bypass. Perfusion. 2000;15:485-94.

48. Cheung AT, Cruz-Shiavone GE, Meng QC, Pochettino A, Augoustides JA, Bavaria JE, et al. Cardiopulmonary bypass, hemolysis, and nitroprussideinduced cyanide production. Anesth Analg. 2007;105:29-33.

49. Kameneva MV, Undar A, Antaki JF, Watach MJ, Calhoon JH, Borovetz HS. Decrease in red blood cell deformability caused by hypothermia, hemodilution, and mechanical stress: factors related to cardiopulmonary bypass. ASAIO J. 1999;45: 307-10.

50. Svenmarker S, Jansson E, Stenlund H, Engström KG. Red blood cell trauma during cardiopulmonary bypass: narrow pore filterability versus free haemoglobin. Perfusion. 2000;15:33-40

51. Serrick CJ, Scholz M, Melo A, Singh O, Noel D. Quality of red blood cells using autotransfusion devices: a comparative analysis. J Extra Corpor Technol. 2003; 35:28-34.

52. Nishiyama T, Hanaoka K. Free hemoglobin concentrations in patients receiving massive blood transfusion during emergency surgery for trauma. Can J Anaesth. 2000; $47: 881-5$

53. Yazer MH, Waters JH, Elkin KR, Rohrbaugh ME, Kameneva MV. A comparison of hemolysis and red cell mechanical fragility in blood collected with different cell salvage suction devices. Transfusion. 2008;48:1188-91.

54. Sakota D, Sakamoto R, Sobajima H, Yokoyama N, Waguri S, Ohuchi K, et al Mechanical damage of red blood cells by rotary blood pumps: selective destruction of aged red blood cells and subhemolytic trauma. Artif Organs. 2008;32: 785-91.

55. Koch CG, Li L, Sessler DI, Figueroa P, Hoeltge GA, Mihaljevic T, et al. Duration of red-cell storage and complications after cardiac surgery. N Engl J Med. 2008; 358:1229-39.

56. Koch CG, Li L, Duncan AI, Mihaljevic T, Cosgrove DM, Loop FD, et al. Morbidity and mortality risk associated with red blood cell and blood-component transfusion in isolated coronary artery bypass grafting. Crit Care Med. 2006; 34:1608-16.

57. Cruz-Landeira A, Bal MJ, Quintela, López-Rivadulla M. Determination of methemoglobin and total hemoglobin in toxicological studies by derivative spectrophotometry. J Anal Toxicol. 2002;26:67-72.

58. Gladwin MT, Kim-Shapiro DB. Storage lesion in banked blood due to hemolysisdependent disruption of nitric oxide homeostasis. Curr Opin Hematol. 2009;16: 515-23.
59. Reynolds JD, Ahearn GS, Angelo M, Zhang J, Cobb F, Stamler JS. S-nitrosohemoglobin deficiency: a mechanism for loss of physiological activity in banked blood. Proc Natl Acad Sci U S A. 2007;104:17058-62.

60. Kato GJ, Gladwin MT. Evolution of novel small-molecule therapeutics targeting sickle cell vasculopathy. JAMA. 2008;300:2638-46.

61. Kelm M, Preik-Steinhoff H, Preik M, Strauer BE. Serum nitrite sensitively reflects endothelial NO formation in human forearm vasculature: evidence for biochemical assessment of the endothelial 1-arginine-NO pathway. Cardiovasc Res. 1999;41:765-72.

62. Lundberg JO, Weitzberg E, Gladwin MT. The nitrate-nitrite-nitric oxide pathway in physiology and therapeutics. Nat Rev Drug Discov. 2008;7:156-67.

63. Weiner DL, Hibberd PL, Betit P, Cooper AB, Botelho CA, Brugnara C. Preliminary assessment of inhaled nitric oxide for acute vaso-occlusive crisis in pediatric patients with sickle cell disease. JAMA. 2003;289:1136-42. Erratum in: JAMA. 2004;292:925.

64. Chang WL, Corate LM, Sinclair JM, van der Heyde HC. Continuous inhaled nitric oxide therapy in a case of sickle cell disease with multiorgan involvement. J Investig Med. 2008;56:1023-7.

65. Lunn RJ. Inhaled nitric oxide therapy. Mayo Clin Proc. 1995;70:247-55.

66. Winterhalter M, Antoniou T, Loukanov T. Management of adult patients with perioperative pulmonary hypertension: technical aspects and therapeutic options. Cardiology. 2010;116:3-9.

67. Cannon RO 3rd, Schechter AN, Panza JA, Ognibene FP, Pease-Fye ME, Waclawiw MA, et al. Effects of inhaled nitric oxide on regional blood flow are consistent with intravascular nitric oxide delivery. J Clin Invest. 2001;108: 279-87.

68. Fox-Robichaud A, Payne D, Hasan SU, Ostrovsky L, Fairhead T, Reinhardt P, et al. Inhaled $\mathrm{NO}$ as a viable antiadhesive therapy for ischemia/reperfusion injury of distal microvascular beds. J Clin Invest. 1998;2497-505.

69. Shiva S, Gladwin MT. Nitrite mediates cytoprotection after ischemia/reperfusion by modulating mitochondrial function. Basic Res Cardiol. 2009;104: 113-9.

70. Raat NJ, Noguchi AC, Liu VB, Raghavachari N, Liu D, Xu X, et al. Dietary nitrate and nitrite modulate blood and organ nitrite and the cellular ischemic stress response. Free Radic Biol Med. 2009;47:510-7.

71. Piknova B, Keszler A, Hogg N, Schechter AN. The reaction of cell-free oxyhemoglobin with nitrite under physiologically relevant conditions: implications for nitrite-based therapies. Nitric Oxide. 2009;20:88-94.

72. Shiva S, Sack MN, Greer JJ, Duranski M, Ringwood LA, Burwell L, et al. Nitrite augments tolerance to ischemia/reperfusion injury via the modulation of mitochondrial electron transfer. J Exp Med. 2007;204:2089-102.

73. Dezfulian C, Raat N, Shiva S, Gladwin MT. Role of the anion nitrite in ischemiareperfusion cytoprotection and therapeutics. Cardiovasc Res. 2007;75:327-38.

74. Zweier JL, Wang P, Samouilov A, Kuppusamy P. Enzyme-independent formation of nitric oxide in biological tissues. Nat Med. 1995;1:804-9.

75. Mack AK, McGowan VR 2nd, Tremonti CK, Ackah D, Barnett C, Machado RF, et al. Sodium nitrite promotes regional blood flow in patients with sickle cell disease: a phase I/II study. Br J Haematol. 2008;142:971-8.

76. Minneci PC, Deans KJ, Shiva S, Zhi H, Banks SM, Kern S, et al. Nitrite reductase activity of hemoglobin as a systemic nitric oxide generator mechanism to detoxify plasma hemoglobin produced during hemolysis. Am J Physiol Heart Circ Physiol. 2008;295:H743-54

77. Lu P, Liu F, Yao Z, Wang CY, Chen DD, Tian Y, et al. Nitrite-derived nitric oxide by xanthine oxidoreductase protects the liver against ischemia-reperfusion injury. Hepatobiliary Pancreat Dis Int. 2005;4:350-5.

78. Duranski MR, Greer JJ, Dejam A, Jaganmohan S, Hogg N, Langston W, et al. Cytoprotective effects of nitrite during in vivo ischemia-reperfusion of the heart and liver. J Clin Invest. 2005;115:1232-40.

79. Dimmeler S, Zeiher AM. Nitric oxide and apoptosis: another paradigm for the double-edged role of nitric oxide. Nitric Oxide. 1997;1:275-81.

80. Goldman DW, Breyer RJ 3rd, Yeh D, Brockner-Ryan BA, Alayash AI. Acellular hemoglobin-mediated oxidative stress toward endothelium: a role for ferryl iron. Am J Physiol. 1998;275(3 Pt 2):H1046-53.

81. Lim YK, Jenner A, Ali AB, Wang Y, Hsu SI, Chong SM, et al. Haptoglobin reduces renal oxidative DNA and tissue damage during phenylhydrazine-induced hemolysis. Kidney Int. 2000;58:1033-44.

82. Azarov I, He X, Jeffers A, Basu S, Ucer B, Hantgan RR, et al. Rate of nitric oxide scavenging by hemoglobin bound to haptoglobin. Nitric Oxide. 2008;18: 296-302.

83. Boretti FS, Buehler PW, D'Agnillo F, Kluge K, Glaus T, Butt OI, et al. Sequestration of extracellular hemoglobin within a haptoglobin complex decreases its 
hypertensive and oxidative effects in dogs and guinea pigs. J Clin Invest. 2009; 119:2271-80.

84. Morariu AM, Loef BG, Aarts LP, Rietman GW, Rakhorst G, van Oeveren W, et al. Dexamethasone: benefit and prejudice for patients undergoing on-pump coronary artery bypass grafting: a study on myocardial, pulmonary, renal, intestinal, and hepatic injury. Chest. 2005;128:2677-87.

85. Chaney MA. Corticosteroids and cardiopulmonary bypass:a review of clinical investigations. Chest. 2002;121:921-31

86. Morris CR, Kuypers FA, Larkin S, Sweeters N, Simon J, Vichinsky EP, et al. Arginine therapy: a novel strategy to induce nitric oxide production in sickle cell disease. Br J Haematol. 2000;111:498-500.

87. Morris CR, Morris SM Jr, Hagar W, Van Warmerdam J, Claster S, KepkaLenhart D, et al. Arginine therapy: a new treatment for pulmonary hypertension in sickle cell disease? Am J Respir Crit Care Med. 2003;168:63-9.

88. Luiking YC, Poeze M, Ramsay G, Deutz NE. Reduced citrulline production in sepsis is related to diminished de novo arginine and nitric oxide production. Am J Clin Nutr. 2009;89:142-52.
89. Wolin MS, Davidson CA, Kaminski PM, Fayngersh RP, Mohazzab-H KM Oxidant-nitric oxide signalling mechanisms in vascular tissue. Biochemistry (Mosc). 1998;63:810-6.

90. Sabaa N, de Franceschi L, Bonnin P, Castier Y, Malpeli G, Debbabi H, et al Endothelin receptor antagonism prevents hypoxia-induced mortality and morbidity in a mouse model of sickle-cell disease. J Clin Invest. 2008;118: 1924-33.

91. Nijboer JM, van der Horst IC, Hendriks HG, ten Duis HJ, Nijsten MW. Myth or reality: hematocrit and hemoglobin differ in trauma. J Trauma. 2007;62: 1310-2.

92. Polaschegg HD. Red blood cell damage from extracorporeal circulation in hemodialysis. Semin Dial. 2009;22:524-31.

93. Bryan NS, Calvert JW, Elrod JW, Gundewar S, Ji SY, Lefer DJ. Dietary nitrite supplementation protects against myocardial ischemia-reperfusion injury. Proc Natl Acad Sci U S A. 2007;104:19144-9.

94. Garg HK, Bryan NS. Dietary sources of nitrite as a modulator of ischemia/reperfusion injury. Kidney Int. 2009;75:1140-4. 